\title{
Transgender in Indonesia According to The Legal, Health and Culture Perspective
}

\author{
Nurul ummah ${ }^{1}$, M. Najeh ${ }^{2}$, and Tongat ${ }^{3}$ \\ \{ nurulummah86@gmail.com ${ }^{1}$, mokh.najih@gmail.com ${ }^{2}$, Tongat@yahoo.com ${ }^{3}$ \} \\ ${ }^{1,2,3}$ Graduate Programs, Faculty of Law, Universitas Muhammadiyah Malang, Indonesia
}

\begin{abstract}
Transgenders are part of a sexual minority group whose orientation differs from the majority of Indonesian society. They are considered to have abnormalities and violate nature, which is inappropriate in Indonesian culture. Yet, based on Ius Constitutum, transgenders have freedom in determining their life. They also have legal protection which are Article 1 (paragraph 3) of 1999 Law no.39 and Article (28) of the 1945 Constitution. However, this human right has limitations related to morals, religion, security and public order. This research aims to perceive transgender from Ius Constitutum, medical and Indonesian culture perspectives, along with its negative and positive impacts.As the result, negative impact experienced by transgender people. Those are isolation from society, activities limitation (namely hanging out, going to the toilet, having religion and socializing), potentially carrying diseases such as HIV-AIDS, and limiting mobility of others who feel uncomfortable about their existence.
\end{abstract}

Keywords: Transgender, Ius Constitutum, Health, Culture, Human Rights.

\section{Introduction}

In society, the environment we choose will influence our behavior later. In terms of personality, people develop through values, rules and norms that apply in the local community. Each community group has a variety of norms, rules and values that are used as role models and represent the development of cultural and religious values in society. When individuals dwell in a community group, they are required to adjust to the values, rules and norms that are already applied in that environment [1].

Society no longer sees transgender, as a new phenomenon. The transgender phenomenon has spread widely, and whether we realize it or not, it has contaminated the community. However, Indonesian still consider transgender behavior to be deviant and violate the norm due to eastern customs and lifestyle [2]. Some countries have started to legalize and recognize the existence of transgender people, such as Germany, India and others. Indonesia has the motto "Bhineka Tunggal Ika" means unity in diversity. Unfortunately these slogans cannot represent the existence of 
lesbians, gays, bisexuals and transgenders or LGBT. This motto indeed aimed at differences in race and ethnicity, not deviant behaviors [3].

At the beginning, transgenders are born with male or female sexuality but then later experience discomfort with their body. They will think the gender is a mistake and claim themselves as different gender. Behaviour change to different gender roles will also occur. Thus, in other word transgender is a contrast feeling with their genitals [4]. Another literature mentioned transgender as a male body that claim their souls as a female and encourage same-sex attraction. Generally, deviant sexual behavior such as homosexual cannot only bee seen from physical or behavoural point of views. Thus, when a homosexual male claim themselves has a gentle personality like a woman, that person are indeed a transgender [5].

The word "transgender" $\mathrm{x}$ is often used to describe someone who feels, thinks and behaves differently from their predetermined sex. Therefore transgender is not only refer to sexual orientation because gender differences can be clasified as homosexual, heterosexual, pansexual, bisexual or asexual. There is significant difference between transgender and transexual. A transgender is not always transexual because gender behavioural change does not always mean genital change. While transexual is part of transgender, because the behavioural and genital changes are completely change themselves due to discomfort [1]. Transexual itself is defined as deviant sexual behavior resulting in a gender disagreement in their mental state, commonly called psychosexual disorders. For example, a male physical body that have female nature and behavior. In some cases, they performing sex change operations to heal their soul. Unfortunately, that is not a proper solution but only for fulfilling an incorrect patient's needs and lust [6].

To exactly define transgender, the terms are diferentiate as gender difference. Thus, transgender divided into two categories namely:

- Transmen, a female born that identifies themselves a male.

- Transwomen, a male born that later identifies themselves a female [4].

Transgender is considered bring bad impact both to the old and young communities and generally defined as deviant behaviour. As a consequence, society feels uncomfortable with their existence and even does not want to live together with them due to bad stigma and influence. It is natural if the community tries to ban and restrict family members from interacting with transgenders [5]. Many transgenders that are experiencing identity search feel their body is not theirs. It causes them to perform genital surgery and be ready to accept nasty consequences and bad society stigma [4]. Indonesian who are not accepting them tend to denounce and discriminate transgender people. Article 1 paragraph 3 of Law No.39 of 1999 concerning Human Rights mentioned discrimination as restriction or exclusion directly or indirectly to human differences based on religion, race, ethnicity, ethnicity, group / class, social and economic status, language, politics, which have an impact on the storage, reduction, elimination of recognition, implementation of human rights with the existence of basic freedoms of life whether individual or whole in the political, economic, social, cultural, legal and other aspects of community life.

However, based on Law No.39/ 1999 concerning Human Rights, transgenders have limits on expressing and exploiting themselves in the public because in contrast with religious values, morals, security and public order. Article 70 of Law Number 39/1999 mentioned that every citizen who apply his rights and freedoms must comply with the limits set by law, with the aim of ensuring the recognition and respect for the rights and freedoms of others and also for the fulfillment of demands that are fair in accordance with moral considerations, security and public 
order. Article 73 of Law Number 39 Year 1999 mentioned that the rights and freedoms set out in the law can only be limited by law as a guarantee in the recognition and respect for human rights, along with the basic freedoms of others, public order, decency and national certainty [7].

Difference sex cannot be a reason to being unfair to certain gender. Changes in people's culture so quickly lead to tolerance of all positive or negative actions, but not as a criminal law. People who have tolerance tend to easily accept new things and are able to encourage society sociocultural change. For example, transvestites as minority groups often receive discrimination, harassment or verbal abuse. Society with humanity values should not perform that action because it is increasing their deterioration and it leads to self-blaming.

\section{Transgender in Current Indonesian Legal Perspective}

In Pure Theory of Law, Hans Kelsen mentioned that humans who live together are marked by an institution establishment that regulates life together named "order". Living together with the individual itself is a biological phenomenon. With regulations in place, it turns into a social phenomenon. Humans who live together have a social order that functions as carriers of certain behaviors collectively from individuals, then encourage them to react positively or negatively. This order arises from complex rules which determine how individuals must behave in accordance with existing norms.

Hans Kelsen points out the characteristic differences derived from all legal arrangements and places them in religious and moral contexts. In every era, society and law are reflections derived from high social concepts. Therefore, it is necessary to show specific techniques to the community. The desired social action from the community can be obtained by the existence of forced regulations applied to deviant behavior [5].

In Indonesian law, transgenders are protected by human rights, as mandated on Article 1 paragraph (3) of Law Number 39 Year 1999 that order society and the state to recognize transgender community's existence. Transgender groups have a basis and guidelines in determining their rights that are regulated in 1945 constitution article J, namely:

- Every citizen has an obligation to respect human rights both in the community, nation and state.

- In applying rights and freedoms, every citizen is obliged to obey restrictions in any form determined by law. Thus, recognition and respect for the rights and freedoms of others are guaranteed. Fair and appropriate demands on moral considerations, religious values, security and order in a democratic society are also fulfilled [7].

Indonesia is a country that recognizes, respects and protects the existence of human rights. Human rights are regulated in chapter XA of the 1945 Constitution. Hierarchically the 1945 Constitution is the highest law used as a reference in making laws and regulations, therefore not a single Indonesian law does not recognize human rights existence. Besides, the country also recognizes 1948 UDHR which was used as international human rights research materials that is known worldwide.

Republic of Indonesia 1945 Constitution Amendment II assertively states that the right to security in Articles 28A-28I and also regulated in Article 30 of Law No.39/ 1999 concerning Human Rights. As written, "Every Indonesian citizen has the right to the sense of security and 
comfort, along with freedom protection in doing something and threats of doing or undoing something". Article 35 of Law No. 39/1999 also stated that every individual has the right to live within society rules or order and being a citizen safely and peacefully which fully respects, implements, protects human rights and its basic obligations as stipulated in this law.

In legal viewpoint, normal sexual acts cannot be criminalized as long as not harming others. Indonesian criminal law does not involve the term LGBT due to its psychological and medical terms. This action can only be classified as criminal conviction once crime occurred, or there is a causal relationship between sexual deviations with those crimes. Homosexuals that become criminals are regulated on Book 2 of the Criminal Code Chapter XIV Article 292 concerning Chastity Crime: "whoever is considered an adult that commits obscene acts with an immature person of the same sex and aknowledge by them or that are appropriate to be suspected of being immature are threatened with a sentence of five years imprisonment" [8].

In sexuality orientation, the existence of gender identity, sexual expression and gender must be in a straight line. The Indonesian Constitution views that human rights have restrictions that must not conflict with religious, moral, security and public order values. Indonesia which is based on Pancasila clearly states in the first principle "Ketuhanan Yang Maha Esa" (God the Almighty). Therefore, religion became the constitution guardian in realizing Indonesia's democratic life. Confirmed by Article 70 that stated "when exercising their rights and freedoms, each person is obliged to obey the predetermined limitations by the Act to guarantee recognition and respect based on the rights and freedoms of others and to fulfill all demands as fairly as possible in accordance with morals, security, and public order in a democratic society".

If LBGT marriage are legalized, it will cause various problems i.e. decreases the birth rate because same-sex marriage cannot produce offspring. Article 1 Law No. 1/1974 concerning Marriage also mentioned that marriage related to the inner bond between man and woman as a husband and wife, which aims to form a happy and eternal family based on the hope of the Almighty God [9]. The intended marriage couple is a heterosexual couple in accordance with article 14 which states "to have a marriage, a prospective husband, wife, marriage guardian, two witnesses and ijab qabul are required". Article 15 paragraph 1 also explains "to obtain the benefit of a family and household, then marriage is only permitted and carried out for prospective brides who are considered to have reached the age specified in article 7 of Law No. 1/2014, a minimum of 19 years as a prospective husband and a minimum of 16 years for prospective wives. Article 16 paragraph 2 states that the bride and groom's approval in the form of a firm and real statement by writing, oral or gesture and silent means there is no explicit rejection. While in article 29 paragraph 3 states that the prospective bride or guardian who objected to the bridegroom, then the marriage contract (akad nikah) can not be implemented. Both articles mentioned clearly stated that the marriage partner is the bride and groom or heterosexual [8].

\section{Transgender in Health Law Perspective}

In general, transgender is a gender dysphoria or can be called gender identity disorder. They assume that their gender identity does not suit their biological sex. The American Psychiatric Association recognizes gender dysphoria as an anxiety condition toward their predetermined gender [6]. 
It should be underlined that this case is not a psychiatric disease. In some cases, gender dysphoria requires medical therapy. Studies in News Medical indicate that this condition is not only due to brain disharmony, but also caused by biological factors related to gender identity before they were born. In the Diagnostic and Statistical Manual of Mental Disorders (DSM-5) book is written that a person cannot be declared as suffering gender dysphoria disorders unless they have shown some symptoms of a differentiation between the gender they believe in and the gender perceived by others. This condition must also run for at least 6 months. This belief lets a person feel that he should not be in a place with a certain gender [10].

WHO has alluded these health conditions in 2018 ICD-11, a new version of the International Disease sections. WHO stated that transgender is no longer a part of mental disorders. Previously, WHO had removed homosexuality from the international classification list of diseases since 1990. As previously reported from the independent WHO completely removed ICD-11 which will take effect on January 1, 2022, so the term gender identity disorder is changed into "gender mismatch" and listed under the chapter related to sexual health and it is no longer classified as mental disorder [11].

In the highest urge level, transgender will change their genitals to obtain full satisfaction as well as adjusting sense and determination of their true identity, so that they can be recognized as normal humans in general. Changes in a person's sex or known as transgender have been known since the development of the Diagnostic and Statistical Manual of Mental Disorder (DSM) method. However, not everyone is able to perform genital change surgery. Based on professional medical opinion, if a person is willing to perform genital surgery they must follow the medical observational procedure in advance. Namely hormonal test, psychological test, personality test that must be done by an expert like psychiatrist, psychologist, genital surgeon, obstetrician and gynecologist. Once a person went through a genital surgery, that means the person already went through a procedural step determined by health experts.

DSM Method in medical science able to track some symptoms associated with discomfort and dissatisfaction in one body part, especially in the sexual anatomy. J. P. Chaplin also mentioned in his book, Dictionary of Psychology, that a person who experiences continuous mental shock for at least two years, has abnormal physical or genetic appearance and has mental disorders i.e. schizophrenia is experiencing psychotic symptoms. The characteristic features are including shut himself up, emotional and affective disorders and negativism behavior. Genital surgery is categorised under plastic surgery and regulated in law No.36 / 2009 concerning health [4].

There are three scopes of sexual orientation, including heterosexual, homosexual and bisexual. Sexual health is aimed at how individuals are able to build relationships and closeness to others and also how individuals are able to express themselves and enjoy love. The term heterosexual means channeling individual desires and emotions to other in reasonable way and considered normal. Transgender sexual orientation is appear because of their sexual orientation nature is different from the original gender and categorized as homosexual. Sometimes they are also called a transvestite, an individual who gains sexual, emotional and spiritual pleasure or satisfaction through gender attributes. Homosexuals and bisexuals are unhealthy sexual orientation that has a greater negative impact on physical and mental health i.e. drinking alcohol, drug abuse, depression and suicide attempts. 
Lesbian and bisexual female are tend to experiencing complex life problems i.e. discrimination and abuse. Unfortunately they find difficulties in rearranging their life and solving their problems, so they easily feel stress and depression. Thus, they seek the solutions through smoking, drinking alcohol and using illegal drugs. Moreover, homosexuals and bisexuals are more vulnerable to contracting HIV or human immunodeficiency virus [12] and sexually transmitted infections or diseases [13]. Sexually transmitted diseases (STDs) is defined as diseases transmitted through one individual to another by sexual contact i.e. Gonorrhea, Syphilis, Herpes and HIV AIDS. Gonorrhea or kencing nanah is caused by gonococcus bacteria that infect reproductive organs and mucous membranes, eyes, anus and other organs. Syphilis or raja singa is caused by treponema pallidum microbe and infecting mucous membranes, anus, mouth, lips and tongue. This disease is transmitted through sexual contact as well as sharing goods with infected people such as towels, clothes, and syringes. The most dangerous STDs are HIV AIDS or Acquired Immunodeficiency Syndrome, started by a decreased human immune system [14].

\section{Transgender in Indonesian Culture Perspective}

In this research, it is assumed that secular and developed countries are more accepting LGBT community rather than developing one. Moreover in non-democratic countries, transgenders almost impossible to practice their rights. Nowadays transgender level is already in alarming number and already spread globally. Spreading of transgender started from pro-LGBT movements since long back. It gained support from the Universal Declaration of Human Rights in 1948. As a developing country, Indonesia also applied human rights on its state philosophy, Pancasila. In interpreting Pancasila, deeper and continuous explanation is still needed, so that human rights can be better applied.

Based on CIA surveys, LGBT community in Indonesia is the fifth largest in the world after China, India, Europe and America. 26 million Facebook users in America are part of LGBT community while Indonesian LGBT is as much as 3 percent of the population, around 7,5 millions people. The United Nations in 2011 estimated there are around 3 million LGBT population undercovered. In 2012 the Ministry of Health released male homosexual (LSL) number as much as 1.095.970 and 5 percent (66.180) of them are infected by HIV. Surprising news from Thailand reported triple gay marriage. Joke, Belle and Art held their marriage on the valentine day, 14 February 2015. Their marriage picture in wedding dress became a global trending topic in social media [15].

Political bureaucracy reform and democracy considered as liberal process, thus transgender are able to expressing themselves in the public sphere, more over after the Reformation Era. Based on Indonesian history, in 1968 there is more positive term to describe homosexual person called "Wadam (Wanita Adam)". Ali Sadikin as Governor of Jakarta facilitated this community by creating the first organization Himpunan Wadam Djakarta (HIWAD) in 1969. Then this term once again changed into "Waria (Wanita Pria)" in 1980 due to objections for the previous term in using the first Moslem Prophet name, Adam Alaihi Salam [2].

Waria's social identity is obtained through cultural group involvement beyond the search process and education. Social identity is formed by ethnicity, race, class, gender and sexuality. Cultural identity includes the acceptance of tradition and learning, the existence of innate traits, language, religion and the existence of cultural heritage in society. The effort to be beautiful, 
speaking gently like a woman, graceful and motherly characteristics, those are transgender effort to express themselves and get recognition from the society. So that they can embrace true identity psychologically by changing themselves biologically and construct the society to accept their existence.

Identity is important in this multicultural world, so that it becomes a central theme in the globalization era. Identity creates new history to the society and brings up a sense of belonging. Identity is always inherent in individuals or communities, and can be a key element in interacting at all levels of society. Psychology theories are explaining gender identity like psychoanalytic theory, social-learning theory and cognitive development. Sigmund Freud (1856-1939) in psychoanalytic theory explained the concept of gender identity formation in each individual and behavior is related to biological factors such as genes, evolution and anatomy [1].

Social-learning theory is naturally explained that different gender roles are the result of environmental demands and expectations. Gender identity itself is the result of society's patriarchal structure. This theory emphasizes social components, as well as culture developed from gender behavior and differences in parenting between women and men. Therefore, by applying reinforcement and imitating concepts, the children will be directed and filled in their respective gender roles. This reinforcement model can be realized well if parents play their role in parenting by giving toys, certain color clothes according to their gender or by giving gifts if they show good behavior and the use of special words for girls and boys [1].

While cognitive development theory emphasizes that interaction between the organism's condition, its cognitive development, along with information on its cultural environment. The existence of a specific behavior towards one gender which behaves specifically is an interaction that exists between cognitive knowledge and information on the society's cultural environment.

Sudikno Mertokusumo believes that: "in society there are several principles, namely religious principles which include revelations from God so that humans become servants of God who are always obedient and devoted, the principles of decency and politeness so that humans behave well, civilized, moral, and virtuous" [4]. Most of Indonesian transgender activists are prefer to adapt well to the current situation rather than changing prior social structure. Culturally they tend to improve creative thinking in solving obstacles, so that society can treat transgenders equally. There are several factors influencing transgender spreading in Indonesia:

- Internal factors

- Family: lack of communication and interaction between family members may cause discomfort and push them to act deviant.

- Moral and behavior factors: transgender is formed from the deviation of society's decency norms as well as wane of social control. Namely sexual stimulation exposure, faded religious faith, lack of self-control and lust.

- Lack of religion understanding: this factor plays huge role since being transgender is violating God's concept of natural human creation and God only allow heterosexual partnership. Religion can be internal factor that influence homosexuality as an ideal defense to educate themselves about rights and wrongs.

- Financial needs: being transgender does not necessarily means limited job offer and cannot be a reason to do inappropriate job.

- External factors:

- Social factors 
- Environment

- Education

- International movement

Puspitosari (2005) in Nurdelia, Jasruddin, and Daud 2015 mentioned factors influencing transgenders transformation, namely biological factors which influenced by sexual and genetic hormones, psychological and socio-cultural factors including parenting in their environment.

Some people in society may understand the reason behind transgenders choice, accepting them as part of society and being friendly with them. Usually those people have broad insight and are highly educated, so they are able to interact with transgender [16]. Unfortunately general society tends to reject them due to discomfort. That is why transgenders often experience scorn, ridicule, violence and exclusion from the community [17]. Particularly for Moslem transgenders that experience trouble in creating Identity Card, limitation in using public facilities and difficulties in finding a proper job.

\section{Conclusion}

Transgender is a behavior that is considered deviate and violate human nature that has been given by God. In law perspective, transgender is protected by human rights, written on Article 30, Article 1 paragraph (3) and Article 35 of Law No.39 of 1999. These Articles are related to the transgender rights to be recognized by the community. In addition, transgender people also have a legal protection basis based on 1999 Law Article J. However, that human rights law is also restricted in articles 70 and 73 of Law Number 39 of 1999.

Transgenders also claimed as homosexual or bisexual that has negative impacts on health. Relationships made by transgender or LGBT people are prone to cause illness among themselves. For example, sharing syringes, towels and clothes, as well as sexual relations with same sex which causing sexually transmitted diseases (STDs) and HIV-AIDS. STDs itself may cause various illnesses namely gonorrhea and syphilis.

Started from $2022 \mathrm{WHO}$ will clasify transgender as gender mismatches and removing current term which was previously referred to gender identity disorder. Nevertheless, gender identity disorder is a psychological and medical disease which is infecting people worldwide and in Indonesia particularly. Transgender percentage in Indonesia reach almost 3\% of the total population and become the fifth largest in the world.

Indonesian society considers transgender as sexual deviant behavior and can have a negative impact on social, religious and norms. Therefore, the society tend to stay away from transgender to avoid contamination from their behaviour. Majority of Indonesian people assume transgender as a transsexual.

Although most people do not acknowledge their existence, transgender people are not discouraged and always try to make their existence recognized, even though they know that their nature is deviant and in terms of health it is also dangerous, but all of that is broken by the urge in themselves that they are human trapped in the genitals in their bodies. Because the different feelings in the reception of his genitals that are considered wrong causes him difficulties in various things. 
Transgender problems begin with identity Card (KTP), limitation in using public facilities, difficulties in carrying out worship (especially Muslims) and often get scorn, ridicule, violence as well as discrimination from various groups.

\section{References}

[1] Nurdelia, Jasruddin, and J. Daud, "Transgender Dalam Persepsi Masyarakat,” J. Equilib. Pendidik. Sosiol., vol. III, no. 1, pp. 19-28, 2015.

[2] R. Roby Yansyah, "Globalisasi Lesbian, Gay, Biseksual, Dan Transgender (LGBT) Perspektif HAM dan Agama Dalam Lingkup Hukum Di Indonesia," J. Law Reform, vol. 14, no. 1, pp. 132-146, 2018.

[3] Fitri Meliya Sari, "Konstruksi Media Terhadap Transgender," Prof. FIS UNIVED, vol. 3, no. 1, pp. 25-34, 2016.

[4] N. H. Kurniawati, E. S. Lestari, S. Aziatin, and dan A. Kristanto, "Transgender dalam Perspektif Hukum Kesehatan," spektrum Huk., vol. 16, no. 2, pp. 52-65, 2019, doi: 10.35973/sh.v16i2.1205.

[5] C. N. Akrom, “Transgender Dalam Perspektif Hukum Positif Dan Hukum Islam,” Islam Negeri Raden Fatah, 2017.

[6] Yunika Isma Setyaningsih, "Perubahan Kelamin Transseksual Dalam Kaitannya Dengan Sistem Kewarisan Islam (Analisa Terhadap Fatwa MUI Berdasarkan Munas DPP MUI ke II/1980)," Islam Negeri Sunan Kalijaga Yogyakarta, 2017.

[7] Ij. Ramadina, "Tinjauan Yuridis Terhadap Transgender ( Transwomen / Waria Analisis Kasus ) Di Kota Makasar," UIN Alauddin Makasar, 2017.

[8] Mulyono, "Perkawinan Lesbian, Gay, Biseksual, dan Transgender dalam Perspektif Hukum Islam dan Hukum Positif," Huk. Islam, vol. 4, no. 1, pp. 101-124, 2019, doi: 10.29240/jhi.v4i1.789.

[9] Rizka Nor Hashela, "Lgbt Dalam Perspektif Hukum Positif Dan Hukum Islam,” Jurnal Hukum Samudra Keadilan, 2019. [Online]. Available: http://www.jdih.tanahlautkab.go.id/berita/detail/lgbt-dalam-perspektif-hukum-positif-.

[Accessed: 13-Mar-2020].

[10] Yudhistira Mahabarata, "Faktanya Indonesia Memang Bukan Tempat yang Tepat untuk Transgender - Voice of Indonesia," 2019. [Online]. Available: https://voi.id/artikel/baca/303/faktanya-indonesia-memang-bukan-tempat-yang-tepat-untuktransgender. [Accessed: 13-Mar-2020].

[11] Giovani Dio Prasasti, "WHO: Transgender Bukan Lagi Gangguan Mental - Health Liputan6," Liputan 6, 2019. [Online]. Available: https://www.liputan6.com/health/read/3987071/who-transgender-bukan-lagi-gangguan-mental. [Accessed: 13-Mar-2020].

[12] S. A. Hasnah, "Lesbian, Gay, Biseksual Dan Transgender (Lgbt) Versus Kesehata: Studi Etnografi," J. Kesehat., vol. 12, no. 1, pp. 63-72, 2019, doi: 10.24252/kesehatan.v12i1.9219.

[13] Dany Noviyani, "Perilaku Seksual Berisiko Infeksi Menular Seksual (Ims) Pada Kelompok Lesbi Di Kota Semarang," J. Heal. Educ., vol. 2, no. 2, pp. 122-129, 2017, doi: 10.15294/jhe.v2i2.22613. 
[14] Shinta Anggraeni Kusuma Ningrum, "Perilaku Kesehatan di Kalangan Transgender (Studi Deskriptif Kualitatif Tentang Perilaku Detection dan Prevention Dalam Teori Tindakan Sosial di Kota Surabaya)," Airlangga, 2016.

[15] Mona Muliasari, I. Lacksana, and Dan Nurul Enggar Permana Sari, "MengintegrasikanNilai-NilaiBudayaIndonesiaDanNilai-

NilaiTeoriRealitaDalamMenghadapiKelompokLGBT," pp. 1-7, 2018.

[16] R. Damayanti, "Pandangan Transgender Terhadap Status Gender dan Persamaan Hak Asasi Manusia di Jakarta, Bogor, Depok dan Tangerang, 2015,” Depok, 2015.

[17] R. S. Kurnia, Widiastuti, F. A. Risakotta, and dan S. Syamsiyatun, "Problem-Problem Minoritas Transgender dalam Kehidupan Sosial Beragama," J. Ilm. Sos. Agama dan Perubahan Sos., vol. 10, no. 2, pp. 83-110, 2016. 